\title{
Attitude of rice farmers towards Green Army Labour Bank (GALB) and agricultural mechanization
}

\author{
Sachu Zachariah John, A. Prema, Binoo P. Bonny and P.K. Sureshkumar
}

Received : 09.05.2018; Revised : 05.09.2018; Accepted : 15.09.2018

\begin{abstract}
Agriculture in Kerala is faced with the agrarian crisis of farmers and farm labourers leaving the sector. The worst hit is rice production which has been the main employment provider for rural population in the state. Green Army Labour Bank (GALB) fostered by the local body of Wadakkanchery Block in Thrissur district of Kerala was organised on the lines of Food Security Army (FSA) of Kerala Agricultural University and started functioning from 2008. It was conceptualised as an efficient work force in the form of labour bank equipped with modern farm techniques and has succeeded in infusing modern methods into conventional farming especially in rice through mechanisation and other labour-saving techniques. Paper describes the results of a systematic study taken upto assess the attitude of rice farmers towards GALB and mechanization in rice. Attitude of rice farmers towards GALB was measured using Likert's summated rating method. Responses from a sample of forty randomly selected rice farmers from the study area was used. Mean attitude score for the sample was 52.25 which indicated overall positive attitude to GALB and farm mechanization. It indicated high reputation of the GALB members among the farmers. Ninety-five per cent of farmers agreed that they preferred GALB for farming operations as GALB showed better efficiency in farm operations. There was also complete agreement among farmers that farming wasmore remunerative and easier with machines compared to manual practices. Hence, there is good scope for mechanization of field operations in other crops and need to be extended throughout the state.
\end{abstract}

KEY WORDS : Green army labour bank, Farmers' attitude, Food security army, Agricultural mechanisation

How to cite this paper : John, Sachu Zachariah, Prema, A., Bonny, Binoo P. and Sureshkumar, P.K. (2018). Attitude of rice farmers towards Green Army Labour Bank (GALB) and agricultural mechanization. Internat. J. Com. \& Bus. Manage, 11(2) : 117-120, DOI: 10.15740/HAS/IJCBM/11.2/117-120. Copyright @2018: Hind Agri-Horticultural Society.

\section{MEMBERS OF THE RESEARCH FORUM}

Correspondence to:

Sachu Zachariah John, Department of Rural Marketing Management, College of Co-operation, Banking and Management, Kerala Agricultural University, Vellanikkara, Thrissur (Kerala) India

Authors' affiliations:

A. Prema, Krishi Vigyan Kendra (KAU), Vellanikkara, Thrissur (Kerala) India

Binoo P. Bonny, Communication Centre, Directorate of Extension (KAU), Mannuthy, Thrissur (Kerala) India

P.K. Sureshkumar, Department of Agricultural Engineering, College of Horticulture, Kerala Agricultural University, Vellanikkara, Thrissur (Kerala) India 